\title{
The hidden Chagas disease burden in Europe
}

P Albajar-Viñas (albajarvinasp@who.int) ${ }^{1}$, Jannin ${ }^{1}$

1. World Health Organization (WHO), Department of Control of Neglected Tropical Diseases, WHO, Geneva, Switzerland

Citation style for this article:

Albajar-Viñas P, Jannin J. The hidden Chagas disease burden in Europe.

Euro Surveill. 2011;16(38):pii=19975. Available online: http://www.eurosurveillance.org/ViewArticle.aspx?Articleld=19975

Chagas disease in non-endemic countries - that is, in countries outside Latin America with exceptional or no vectorial transmission such as in Europe - has come to light since the beginning of 2000. The emergence of the disease in those countries was mainly linked to population mobility, notably migration. During the last century, Chagas disease cases were detected in nonendemic countries in North America (Canada and the United States) and the Western Pacific Region (mainly Australia and Japan), and only more recently in Europe $[1,2]$.

The history of Chagas disease in Europe can be divided in three significant periods. The initial period, started at the beginning of the 1980s, when the first Chagas disease case in Europe was published [3], 72 years after Carlos Ribeiro Justiniano Chagas discovered the disease in Brazil [4]. Since then, successive sporadic publications have started to draw attention to the existence of Chagas disease cases in different European countries and the existence of the responsible parasite Trypanosoma cruzi. These publications describe infection transmission in Europe through different non-vectorial routes such as transfusional, congenital and laboratory-accident transmission, as well as sporadically through the arrival of infected travellers such as tourists, people visiting friends and relatives and adopted children [5].

The year 2000 marked the beginning of a second period, characterised by an increase in the number of cases reported in the scientific literature in many European countries [6]. According to the International Organization for Migration an important increase of migration between Europe and Latin America, predominantly to southern European countries, and mainly to Spain, was documented. Major causes contributing to this migration phenomenon were the economic hardship caused by the recession and high poverty levels in Latin America and tightening of visa regimes in the United States after 2001. The close cultural and historic ties of Latin American countries to Europe and the possibility for many Latin Americans to appeal to dual nationality because they frequently have European ancestors, have also facilitated population mobility in that direction. Demographically, the migrant population was young, with high rates of labour force participation and relatively high rates of educational attainment, with great capacity to integrate into European societies. Additionally, they represented a prime example of the current worldwide trend towards the feminisation of migration, which is relevant in the context of Chagas disease because of the possibility of congenital transmission from infected mothers. Finally, there was also a significant number of undocumented migrants, and that irregular migration posed a significant challenge to governments [7].

The year 2007 marked the beginning of a third period in the history of Chagas disease in Europe, characterised by various initiatives launched at different levels. In July 2007, the World Health Organization (WHO) and the Pan American Health Organization (PAHO) convened a meeting entitled Revisiting Chagas disease: from a Latin American health perspective to a global health perspective, with participants of 28 Latin American and non-Latin American countries where the disease was present. A major outcome of the meeting was to highlight the presence of $T$. cruzi infection outside Latin America in the so-called non-endemic countries and an initiative to deal with Chagas disease in non-endemic countries, supplementing the existing intergovernmental initiatives for the control of Chagas disease in Latin America [8].

With the main objectives of assessing the burden of Chagas disease as a public health problem in nonendemic countries and formulating an appropriate response, the WHO organised a series of meetings in 2008 and 2009 that culminated in the Informal Consultation on the Control and Prevention of Chagas disease in Europe, in the first profiles of European countries with Chagas disease cases and the first statement acknowledging that the disease has emerged as an important public health challenge $[5,9]$.

In May 2010 the 63rd World Health Assembly approved the new resolution WHA63.20 which recognises the increased number of cases of Chagas disease in countries where the disease is not endemic and states that all transmission routes have to be tackled. It further promotes the integration of patients with acute and 
chronic clinical forms of Chagas disease into primary health services and calls for a mobilisation of national and international, public and private financial and human resources, for the promotion of intersectorial efforts and collaboration, and for the facilitation of networking between organisations and partners [10]. The 63rd World Health Assembly also called for the establishment of an initiative of non-endemic countries aiming at interconnecting all those regions and countries that have patients. Finally, in October 2010, the first WHO report on neglected tropical diseases included Chagas disease as one of the 17 listed diseases [2].

From the point of view of the legal framework, the first official reference to Chagas disease at the European Union level was made in the European Commission's Directive 2004/23/CE [11] amending Directive 2002/98/ CE [12] of the European Parliament and Council (2003) on quality and safety of blood, which concerns technical criteria relating to blood and blood donations. Annex III of the directive defines the admission criteria for blood donors or blood types and the minimal exclusion criteria for donations from donors who have or had parasitological diseases; the exclusion of Chagas disease carriers is specified. Other European directives, including 2005/62/CE, establish norms to be followed by institutions when carrying out blood transfusions with blood imported from other countries. In February 2006, the European Parliament published a new directive 2006/17/CE [13] on the donation and control of human tissues and cells, which referred to Chagas disease. The directive relates to the screening of donors based on their epidemiological history and travel to endemic areas. Aligned with European Union directives, France, Spain and the United Kingdom implemented national measures to control transfusional transmission of Chagas disease $[14,15]$.

The present timely special edition of Eurosurveillance, published in two parts, is a useful instrument to review and update diverse aspects of Chagas disease in Europe related to topics such as the current epidemiological situation, primary and secondary prevention of T. cruzi infection, including congenital cases, control of transmission by transfusion and organ transplantation, care of patients, information, education and communication instruments, and the information and surveillance systems in place in countries within and outside of the European Union.

Basile et al. [16] review the epidemiological situation of the nine European countries with the highest estimated prevalence of $T$. cruzi infection, and the difficulties of dealing with a frequently silent and under- or misdiagnosed disease for which neither acute nor chronic cases are captured by compulsory notification. They point out the need for and challenge of an information and surveillance system in Europe that considers also the number of undocumented migrants. The lack or inconsistency of accurate epidemiological numbers of people with $T$. cruzi infection or Chagas disease can perpetuate the vicious circle of a silent and, in a way, silenced disease.

Along the same lines, the characteristics of patients attended and documented in the EuroTravNet provide precious information on the epidemiological and clinical profile of most of patients, together with the urgent necessity of implementing active measures to increase detection and access to diagnosis and treatment [17]. Other very interesting examples describing possible mechanisms to increase detection and care, and to make the disease more visible, are offered in articles from Italy and Switzerland $[18,19]$. These are countries with high absolute and relative numbers of $T$. cruzi-infected people, especially in certain regions or cantons. They have even seen reported acute cases of congenital transmission or oral transmission in a tourist coming back from a short trip to an endemic country. The need of an interdisciplinary approach, from the medical to the sociological sciences, taking into account all involved actors, including the patients themselves, is appointed as the unique solution to break the disease silence [20].

In terms of the possibility of implementing secondary prevention of congenital transmission linked to an information system in Europe, two pioneer experiences from Spain illustrate faced challenges and successful strategic measures to enhance the number of screened mothers and limit the number of lost patients in the after birth follow-up [21,22]. Nevertheless, as described by Navarro et al., implementing a protocol for the screening of pregnant women and the early diagnosis of infected newborns and their siblings requires also an essential component of information, education and communication (IEC), adapted to the emotional meaning Chagas disease for the affected population and their knowledge about it [23]. Moreover, any IEC component should include all involved actors, from health personnel to patients, including local nongovernmental associations. Also from Spain comes a significant study by Valerio et al. reviewing the epidemiological data of T. cruzi infection and Chagas disease clinical chronic manifestations, especially in groups at risk of being infected. These studies evidence that it is essential to know the characteristics of the migrated population in terms of age, country of origin and exposition to infection, in order to propose adequate costeffective protocols for laboratory and clinical screening and diagnosis, patient care and preventive and control measures $[23,24]$.

It is necessary to move ahead with the description of Chagas disease in Europe. At-risk groups of migrants who lived in endemic areas before Chagas disease control measures were implemented in Latin America can have a high prevalence of infection and disease. But it is also logical to think that Chagas disease in nonendemic countries, with a reduced possibility of reinfection or co-infections with other parasitic diseases, with high standards of hygiene and nutritional status, 
could be characterised by a lower morbidity and mortality. We are convinced that this special issue will stimulate further lively discussions around this disease, but also the implementation of the necessary measures to make it visible, stop transmission and provide care to patients in Europe.

\section{References}

1. Coura JR, Viñas PA. Chagas disease: a new worldwide challenge. Nature. 2010;465(7301):S6-7.

2. World Health Organization (WHO). Working to overcome the global impact of neglected tropical diseases: first WHO report on neglected tropical diseases. Geneva: WHO; 2010. Available from: http://www.who.int/neglected_diseases/2010report/en/

3. Pehrson PO, Wahlgren M, Bengtsson E. Asymptomatic congenital Chagas' disease in a 5-year-old child. Scand J Infect Dis. $1981 ; 13(4): 307-8$.

4. Chagas C. Nova tripanozomiase humana. Estudos sobre a morfolojía e o ciclo evolutivo de Schizotrypanum cruzi n. gen., n. sp., ajente etiolójico de nova entidade morbida do homen. [New human trypanozomiasis. Studies on the morphology and evolutionary cycle of Schizotrypanum cruzi n. gen., n. sp., aetiological agent of a new human morbid entity]. Mem Inst Oswaldo Cruz. 1909;1:159-218. Portuguese.

5. World Health Organization (WHO). Control and prevention of Chagas disease in Europe. Report of a WHO Informal Consultation (jointly organized by WHO headquarters and the WHO Regional Office for Europe) Geneva, Switzerland, 17-18 December 2009. Final report. Geneva: WHO; 2010. Report No.: WHO/HTM/NTD/IDM/2010.1. Available from: http://www. fac.org.ar/1/comites/chagas/Chagas_WHO_Technical\%20 Report_16_06_10.pdf

6. Schmunis GA. Epidemiology of Chagas disease in non-endemic countries: the role of international migration. Mem Inst Oswaldo Cruz. 2007;102 Suppl 1:75-85.

7. International Organization for Migration. Migration from Latin America to Europe: trends and policy challenges. IOM Migration Research Series No. 16. Geneva: IOM; 2004. Available from: http://publications.iom.int/bookstore/index. php?main_page=product_info\&products_id=199

8. World Health Organization (WHO). New global effort to eliminate Chagas disease. Geneva: WHO; 3 July 2007. Available from: http://www.who.int/mediacentre/news/releases/2007/ pr36/en/index.html

9. Angheben A, Bartoloni A, Anselmi M, Gradoni L, Bottieau $\mathrm{E}$, Carlier Y et al. Infection à Trypanosoma cruzi/maladie de Chagas en Europe. Conclusions du sixième congrès européen de médecine tropicale et santé internationale. [Trypanosoma cruzi/Chagas disease in Europe. Conclusions of the sixth European congress of tropical medicine and international health]. Bull Soc Pathol Exot. 2010;103:359-63.

10. World Health Organization (WHO). Chagas disease: control and elimination. A63/20. 63rd World Health Assembly. Geneva, 1822 May 2009. Available from: http://www.who.int/neglected diseases/mediacentre/WHA 63.20 Eng.pdf

11. European Commission. Directive $2004 / 23 /$ EC of the European Parliament and of the Council of 31 March 2004 on setting standards of quality and safety for the donation, procurement, testing, processing, preservation, storage and distribution of human tissues and cells. Official Journal of the European Union. L 102/48. Luxembourg: Publications Office of the European Union; 2004. Available from: http://eur-lex.europa. eu/LexUriServ/LexUriServ.do?uri=0J:L:2004:102:0048:0058:E $\mathrm{N}: \mathrm{PDF}$

12. European Commission. Directive 2002/98/EC of the European Parliament and of the Council of 27 January 2003 setting standards of quality and safety for the collection, testing, processing, storage and distribution of human blood and blood components and amending Directive 2001/83/EC. Official Journal of the European Union. L 33/30. Luxembourg: Publications Office of the European Union; 2003. Available from: http://eur-lex.europa.eu/LexUriServ/LexUriServ.do?uri= OJ:L:2003:033:0030:0040:EN:PDF

13. European Commission. Commission Directive 2006/17/EC of 8 February 2006 implementing Directive 2004/23/EC of the European Parliament and of the Council as regards certain technical requirements for the donation, procurement and testing of human tissues and cells. L 38/40. Luxembourg: Publications Office of the European Union; 2006. Available from: http://eur-lex.europa.eu/LexUriServ/LexUriServ.do?uri= OJ:L:2006:038:0040:0052:EN:PDF
14. Rapport d'activités 2006. [Report of activities 2006]. La Plaine saint-Denis: Établissement français du Sang; 2007.

15. Real Decreto $1088 / 2005$, de 16 de septiembre, por el que se establecen los requisitos técnicos y condiciones mínimas de la hemodonación y de los centros y servicios de transfusión. [Royal Decree 1088/2005 of 16 September establishing the minimum technical requisites and conditions for blood donation and for blood transfusion centres and services]. Boletín Oficial del Estado. 2005;225:31288-304. Madrid: Ministerio de Sanidad y Consumo; 2005. Available from: http://www.boe.es/boe/dias/2005/09/20/pdfs/A31288-31304. pdf

16. Basile L, Jansà JM, Carlier Y, Salamanca DD, Angheben A, Bartoloni A, et al. Chagas disease in European countries: the challenge of a surveillance system. Euro Surveill. 2011;16(37):pii=19968. Available from: http://www. eurosurveillance.org/ViewArticle.aspx?Articleld=19968

17. Perez-Molina JA, Perez-Ayala A, Parola P, Jackson Y, Odolini S, Lopez-Velez R, et al. EuroTravNet: imported Chagas disease in nine European countries, 2008 to 2009. Euro Surveill. 2011;16(37):pii=19966. Available from: http://www. eurosurveillance.org/ViewArticle.aspx?Articleld=19966

18. Angheben A, Anselmi M, Gobbi F, Marocco S, Monteiro G, Buonfrate D, et al. Chagas disease in Italy: breaking an epidemiological silence. Euro Surveill. 2011;16(37):pii=19969. Available from: http://www.eurosurveillance.org/ViewArticle. aspx?Articleld=19969

19. Jackson Y, Chappuis F. Chagas disease in Switzerland: history and challenges. Euro Surveill. 2011;16(37): pii=19963. Available from: http://www.eurosurveillance.org/ViewArticle. aspx?Articleld $=19963$

20. Di Girolamo C, Bodini C, Marta BL, Ciannameo A, Cacciatore F. Chagas disease at the crossroad of international migration and public health policies: why a national screening might not be enough . Euro Surveill. 2011;16(37): pii=19965. Available from: http://www.eurosurveillance.org/ViewArticle. aspx?Articleld $=19965$

21. Flores-Chavez MD, Merino FJ, García-Bujalance S, MartinRabadán P, Merino P, García-Bermejo I, et al. Surveillance of Chagas disease in pregnant women in Madrid, Spain, from 2008 to 2010. Euro Surveill. 2011;16(38):pii=19974. Available from: http://www.eurosurveillance.org/ViewArticle. aspx?Articleld $=19974$

22. Basile L, Oliveira I, Ciruela P, Plasencia A, working group for developing the Catalonian Screening Programme for congenita transmission of Chagas disease. The current screening programme for congenital transmission of Chagas disease in Catalonia, Spain. Euro Surveill. 2011;16(38):pii=19972. Available from: http://www.eurosurveillance.org/ViewArticle. aspx?Articleld $=19972$

23. Navarro M, Perez-Ayala A, Guionnet A, Perez-Molina JA, Navaza B, Estévez L, et al. Targeted screening and health education for Chagas disease tailored to at-risk migrants in Spain, 2007 to 2010. Euro Surveill. 2011;16(38):pii=19973. Available from: http://www.eurosurveillance.org/ViewArticle. aspx?Articleld $=19973$

24. Valerio L, Roure S, Sabrià M, Balanzó X, Vallès X, Serés L. Clinical, electrocardiographic and echocardiographic abnormalities in Latin American migrants with newly diagnosed of Chagas disease 2005-2009, Barcelona, Spain. Euro Surveill, 2011;16(38):pii=19971. Available from: http:// www.eurosurveillance.org/ViewArticle.aspx?Articleld=19971 